\title{
PENGARUH LATIHAN SENAM KEBUGARAN JASMANI (SKJ) TERHADAP TINGKAT KEBUGARAN SISWA KELAS V DI MIN DONOMULYO KABUPATEN MALANG
}

\author{
Zainul Arifin \\ STAI Ma'had Aly Al-Hikam Malang \\ Email: zainularifin970@gmail.com
}

\begin{abstract}
Abstrak
Kebugaran jasmani peserta didik merupakan aspek penting yang dapat meningkatkan mobilitas dalam meraih prestasi akademik secara maksimal. Upaya meningkatkan kebugaran jasmani peserta didik dapat melalui berbagai aktifitas fisik yang salah satunya adalah kegiatan SKJ. Penelitian ini bertujuan untuk mengetahui secara jelas tentang pengaruh latihan SKJ terhadap tingkat kebugaran jasmani siswa kelas V di MIN Donomulyo Kabupaten Malang. Hasil penelitian diharapkan dapat membantu meningkatkan pengetahuan tentang kebugaran jasmani melalui SKJ. Penelitian ini termasuk jenis penelitian kuantitatif dengan menggunakan pendekatan metode eksperimental, sementara treatment yang dilakukan adalah 3 kali dalam seminggu. Sampel yang digunakan adalah siswa kelas V di MIN Donomulyo Kabupaten Malang. Hasil penelitian dan analisis data yang telah dilakukan terhadap latihan senam kebugaran jasmani 3 kali seminggu terdapat peningkatan kebugaran jasmani pada siswa kelas 5 di MIN Donomulyo Kabupaten Malang.
\end{abstract}

Kata Kunci: Latihan, Kebugaran Jasmani

\section{A. PENDAhuluan}

Kebugaran jasmani suatu bangsa dapat dijadikan tolak ukur yang menunjukkan taraf kesehatan suatu bangsa. Dalam dunia pendidikan kebugaran jasmani peserta didik merupakan aspek penting yang dapat meningkatkan mobilitas dalam meraih prestasi akademik secara maksimal. Kebugaran jasmani di sekolah dapat diperoleh secara maksimal melalui mata pelajaran PJOK maupun kegiatankegiatan ekstrakulikuler yang memaksimalkan gerak fisik secara menyeluruh. Upaya meningkatkan kebugaran jasmani peserta didik dapat melalui berbagai aktifitas fisik yang salah satunya adalah kegiatan SKJ.

Senam berasal dari Bahasa Yunani "gymnos" yang artinya telanjang. Dalam Bahasa Inggris dikenal dengan istilah "gymnastic" yang berarti menerangkan bermacam-macam gerak yang dilakukan oleh seseorang yang telanjang. Hal ini dapat terjadi dikarenakan pada waktu itu teknologi pembuatan bahan pakaian belum memungkinkan untuk membuat pakaian yang bersifat lentur dan mengikuti gerak pemakainya. Senam adalah setiap bentuk latihan fisik yang disusun secara sistematis dengan gerakan-gerakan yang terpilih dan terencana untuk mencapai tujuan tertentu. $^{1}$ FIG (Federation Internationale De Gymnastique) senam dapat dikelompokan menjadi 6 yaitu: Senam Artistik (Artistic Gymnastics), Senam Ritmik Sportif (Sportive Rhytmic Gymnastics), Senam Akrobatik (Acrobatic Gymnastics), Senam Aerobik Sports (Sports Aerobik), Senam Trampolin (Trampolinning), Senam Umum (General Gymnastics).

\footnotetext{
${ }^{1}$ Muhajir, Pendidikan Jasmani, Olahraga, dan Kesehatan, (Jakarta, 2007), hlm. 69.

Vol. 1 No. 1 / April 2018

$\mathrm{Al}$ - Mudarris homepage: http://e-journal.staima-alhikam.ac.id/index.php/al-mudarris/
} 
Dalam peningkatan kebugaran jasmani tidak bisa dilakukan secara instan, perlu adanya proses latihan yang berkelanjutan dan dilakukan secara terus menerus untuk mendapatkan hasil yang maksimal. Dalam dunia pendidikan khususnya pada tingkat satuan pendidikan sekolah dasar dapat dioptimalkan kegiatan senam secara berkala, hal ini dapat mengoptimalkan pertumbuhan fisik secara maksimal. Pentingnya kebugaran tubuh bagi peserta didik mempunyai peran besar dalam pertumbuhan fisik peserta didik.

\section{LATIHAN}

Latihan adalah suatu proses penyempurnaan atau pendewasaan atlet secara sadar untuk mencapai mutu prestasi maksimal dengan diberi beban fisik dan mental yang teratur dan terarah meningkatkan dan berulang-ulang waktunya. ${ }^{2}$ Latihan merupakan cara untuk mendapatkan hasil secara maksimal yang dilakukan secara berulang-ulang.

1. Prinsip-prinsip latihan

a. Prinsip beban bertambah : Pemberian beban latihan harus melebihi kebiasaan kegiatan sehari-hari secara teratur. Hal ini bertujuan agar sistem fisiologis dapat menyesuaikan dengan tuntutan fungsi yang dibutuhkan untuk kemampuan tinggi. ${ }^{3}$

b. Prinsip spesialisasi : Latihan bersifat khusus sesuai dengan kebutuhan olahraga dan pertandingan yang akan dilakukan. Perubahan anatomis dan fisiologis dikaitkan dengan kebutuhan olahraga dan pertandingan. ${ }^{4}$

c. Prinsip individual : Latihan harus memperhatikan dan memperlkukan atlet sesuai dengan tingkatan kemampuan, potensi, karakteristik belajar, dan kekhususan olahraga. Seluruh konsep latihan harus direncanakan sesuai dengan karkteristik fisiologis dan psikologis atlet, sehingga tujuan latihan dapat ditingkaatkan secara wajar. ${ }^{5}$

d. Prinsip variasi : Latihan harus bervariasi dengan tujuan untuk mengatasi sesuatu yang monoton dan membossankan dalam latihan.

e. Prinsip beban meningkat bertahap : Pemberian beban latihan harus ditingkatkan secara bertahap, teratur, dan ajeg hingga mencapaibeban maksimum. ${ }^{6}$

f. Prinsip perkembangan multilateral : Perkembangan multilateral meliputi seluruh organ dan sistem manusia, serta antara proses fisiologis dan psikologis.

g. Prinsip pulih asal : Proses pemulihan kembali glikogen otot dan cadangan phospagen, menhilangkan asam laktat dan metabolisme lainnya, reoksigenasi mioglobin dan mengganti protein.

\footnotetext{
${ }^{2}$ Suharno, Ilmu Coaching umum, (Yogyakarta: FKIK IKIP Yogyakarta, 1986), hlm. 7.

${ }^{3}$ Bompa, Periodization theory and methodology of training, (United states: Human kinetics, 2009), hlm 42.

${ }^{4}$ Bompa, Periodization theory and methodology of training, (United states: Human kinetics, 2009), hlm 42.

${ }^{5}$ Bompa, Periodization theory and methodology of training, (United states: Human kinetics, 2009), hlm 42.

${ }^{6}$ Bompa, Periodization theory and methodology of training, (United states: Human kinetics, 2009), hlm 42.
}

Vol. 1 No. 1 / April 2018

$\mathrm{Al}$ - Mudarris homepage: http://e-journal.staima-alhikam.ac.id/index.php/al-mudarris/ 
h. Prinsip reversibilitas : Menunjuk pada hilangnya secara pelan-pelan pengaruh latihan jika intensitasnya, lama latihan dan frekuensinya dikurangi.

2. Manfaat Latihan Terhadap Tubuh

Manfaaat latihan jika dilakukan secara teratur akan sangat baik terhadap tubuh karena dari latihan itu dapat memperoleh kesehatan baik jasmani maupun rohani, hal ini dikarenakan dalam latihan fisik kinerja otot maupun organ-organ lainnya dalam di dayagunakan secara maksimal.

\section{KEBUGARAN JASMANI}

Kebugaran jasmani merupakan kondisi tubuh seseorang, yang mempunyai peranan penting dalam kegiatan atau aktivitas sehari-hari. Setiap individu perlu memiliki tingkat kebugaran jasmani yang ideal. Hal itu disesuaikan dengan tuntutan tugas maupun aktivitas dalam kehidupan sehari-hari. Kebugaran jasmani adalah kemampuan tubuh seseorang untuk melakukan tugas pekerjaan sehari-hari, tanpa menimbulkan kelelahan yang berarti. ${ }^{7}$ Kebugaran jasmani yang baik merupakan modal dasar bagi seseorang untuk melakukan aktivitas fisik atau kerja sehari-hari secara efisien dalam waktu yang relatif lama tanpa adanya kelelahan yang berarti sehingga masih bisa menikmati waktu luangnya. Kebugaran jasmani bisa didapatkan melalui latihan fisik yang tepat, sistematis, dan tidak berlebihan.

Dari uraian di atas dapat disimpulkan bahwa kebugaran jasmani bentuk ketahanan fisik manusia dalam melakukan berbagai macam bentuk aktivitas dalam kehidupan sehari-hari, tanpa menimbulkan kelelahan yang berarti. Sehingga, masih terdapat sisa tenaga yang dapat digunakan untuk beraktifitas secara spontan, dimana seseorang yang memiliki tingkat kebugaran kurang tidak dapat melakukannya.

1. Komponen kebugaran jasmani

a. Daya tahan (endurance)

Daya tahan (endurance) adalah kemempuan untuk melakukan suatu gerakan atau usahamelewati suatu periode waktu. ${ }^{8}$

b. Kelentukan (flexibility)

Kelentukan (flexibility) adalah kemampuan sendi untuk melakukan gerakan dalam ruang gerak sendi secara maksimal sesuai dengan kemungkinan geraknya.

c. Kekuatan (strength)

Kekuatan (strength) adalah besarnya tenaga yang digunakan oleh otot atau sekelompok otot saat melakukan kontraksi.

d. Komposisi tubuh

Komposisi tubuh dapat didefinisikan sebagai prosentasi relatif dari lemak tubuh dan massa tubuh.

e. Kecepatan (speed)

Kecepatan (speed) adalah kemampuan berpindah dengan cepat dari satu tempat ke tempat lain. ${ }^{9}$ Kecepatan adalah kemampuan seseorang untuk mengerjakan gerakan berkesinambungan dalam bentuk yang sama dalam waktu yang sesingkat-singkatnya (Sajoto, 1988). Jadi kecepatan

\footnotetext{
${ }^{7}$ Nurhasan, Tips Praktis Menjaga Kebugaran Jasmani, (Gresik: Abil Pustaka, 2011), hlm. 12.

${ }^{8}$ Nurhasan, Tips Praktis Menjaga Kebugaran Jasmani, (Gresik: Abil Pustaka, 2011), hlm. 15

${ }^{9}$ Nurhasan, Tips Praktis Menjaga Kebugaran Jasmani, (Gresik: Abil Pustaka, 2011), hlm. 15.
} Vol. 1 No. 1 / April 2018

$\mathrm{Al}$ - Mudarris homepage: http://e-journal.staima-alhikam.ac.id/index.php/al-mudarris/ 
merupakan usaha yang dilakukan secara cepat untuk berpindah dari satu tempat ke tempat yang lain secara berkesinambungan dalam bentuk yang sama.

f. Keseimbangan(balance)

Keseimbangan(balance) adalah kemampuan mempertahankan sikap dan posisi tubuh pada bidang tumpuan pada saat berdiri (static balance) atau pada saat melakukan gerakan (dynamic static). ${ }^{10}$ Keseimbangan diperlukan unsur-unsur koordinasi, ketangkasan, dan kelincahan (Moeslim, 1995). Jadi keseimbangan adalah sebuah bentuk keadaan dalam mempertahankan keadaan yang keseimbangan, pada saat diam maupun pada saat bergerak.

g. Kelincahan (agility)

Kelincahan (agility) adalah kemampuan bergerak dengan berubah-ubah arah secara cepat dan tepat tanpa kehilangan keseimbangan. Kelincahan adalah kemampuan seseorang untuk merubah arah dan posisi di arena tertentu. Dapat disimpulkan bahwa kelincahan (agility) berhubungan dengan kemampuan yang dilakukan secara cepat dan tepat dalam mengubah arah posisi tubuh dengan kecepatan dan ketepatan yang maksimal, tanpa harus kehilangan keseimbangan.

h. Koordinasi (coordination)

Koordinasi (coordination) adalah kemampuan untuk melakukan gerak dengan tepat dan efisien. ${ }^{11}$ Koordinasi (coordination) adalah kemampuan seseorang mengintegrasikan bermacam-macam gerakan yang berbeda dalam pola gerakan tunggal secara efektif (Sajoto 1988). Jadi koordinasi dapat diartikan dengan kemampuan untuk menggunakan organ penglihatan maupun pendengaran dan bersamaan dengan bagian-bagian tubuh tertentu dalam melakukan aktivitas gerak atau motorik dengan baik dan ketepatan maksimal.

i. Kecepatan reaksi (reaction speed)

Kecepatan reaksi (reaction speed) berkaitan dengan waktu yang diperlukan dari saat diterimanya stimulus atau rangsangan sampai awal munculnya respon atau reaksi.

j. Daya (power)

Daya (power) adalah gabungan antara kekuatan dan kecepatan atau pengerahan otot secara maksimal dengan kecapatan maksimum. Daya ledak merupakan unsur kemampuan fisik yang menjadikan seseorang mampu menggunakan otot-otot untuk menghasilkan gerak fisik secara explosif (Sugiyanto, 1998)

2. Faktor-faktor yang mempengaruhi kebugaran jasmani

Pada dasarnya kebugaran jasmani dipengaruhi oleh dua faktor utama yang terbagi menjadi faktor internal dan faktor eksternal. Faktor internal merupakan faktor yang sudah melekat dan menetap pada seorang individu, seperti faktor genetik, usia, maupun jenis kelamin. Sedangkan faktor eksternal ini merupakan faktor yang terdapat atau diperoleh dari luar seperti latihan, aktivitas fisik, gaya hidup, status gizi, dll.

a. Genetik

\footnotetext{
${ }^{10}$ Nurhasan, Tips Praktis Menjaga Kebugaran Jasmani, (Gresik: Abil Pustaka, 2011), hlm. 16.

${ }^{11}$ Nurhasan, Tips Praktis Menjaga Kebugaran Jasmani, (Gresik: Abil Pustaka, 2011), hlm. 17
} Vol. 1 No. 1 / April 2018

$\mathrm{Al}$ - Mudarris homepage: http://e-journal.staima-alhikam.ac.id/index.php/al-mudarris/ 
Faktor genetik merupakan faktor keturunan yang dipreroleh sejak lahir yang didapat dari kedua orang tua. Faktor keturunan adalah sifat-sifat bawaan yang dibawah sejak lahir, yang didapat dari sifat kedua orang tua. Pengaruh genetik terhadap kekuatan otot dan ketahanan otot pada umumnya berhubungan dengan banyaknya serabut otot dan komposisi serabut otot merah dan putih. ${ }^{12}$

b. Usia

Faktor umur sangat berpengaruh pada kebugaran jasmani. Hal ini dapat dilihat kinerja kardiovaskuler, dimana kinerja kardiovaskuler akan melemah seiring dengan bertambahnya usia, tetapi melemahnya kardiovaskuler ini bisa diminimalisasi dengan serangkaian kegiatan olahraga secara teratur.

c. Jenis kelamin

Nilai kebugaran jasmani yang dicerminkan melalui volume oksigen maksimal (VO2 Max) laki-laki lebih besar dari nilai volume oksigen maksimal (VO2 Max) perempuan berkisar antara 15-30\%, walaupun antar atlet yang terlatih sekalipun. Perbedaan ini akan sangat besar jika dinyatakan ke nilai absolut (liter per menit). Pada umunya perubahan ini disebabkan oleh perubahan komposisi tubuh dan perbedaan kandungan $\mathrm{Hb}^{13}$

d. Latihan

Menurut Djoko (2004) mendefinisikan latihan kebugaran sebagai proses sistematis menggunakan gerakan bertujuan meningkatkan atau mempertahankan kualitas fungsi tubuh yang meliputi kualitas daya tahan paru-paru dan jantung, kekuatan dan daya tahan otot, kelentukan dan komposisi tubuh. Pada dasarnya latihan sangat mempengaruhi semua komponen kebugaran jasmani, latihan yang dilakukan secara baik dan benar bisa meningkatkan fungsi dan kinerja kardiovaskuler. Menurut Nurhasan (2011) latihan olahraga dapat meningkatkan kesegaran jasmani, bila memenuhi syarat-syarat sebagai berikut:

1) Intensitas latihan, yaitu beratnya kegiatanfisik dan merupakan faktor utama yang mempengaruhi kemampuan faal tubuh,

2) Frekuensi latihan, yaitu jumlah kegiatan fisik yang dilakukan dalam jangka waktu satu minggu, dan

3) Lama latihan, yaitu waktu yang digunakan dalam melakukan latihan fisik.

e. Gaya hidup

Gaya hidup juga berpengaruh terhadap kebugaran jasmani, jika seseorang ingin memperoleh kebugaran jasmaninya tetap baik dan terjaga, maka perlu menerapkan cara hidup yang sehat dalam kehidupan sehari-hari, seperti makan makanan yang bersih, sehat dan bergizi, serta menjaga dan memelihara tubuh dengan baik.

f. Status gizi

Kualitas gizi seseorang mulai di dalam kandungan pada masa-masa pertumbuhan berikutnya mempunyai pengaruh yang besar terhadap perkembangan jasmani maupun kecerdasan seseorang. Status gizi merupakan

${ }^{12}$ Nurhasan, Tips Praktis Menjaga Kebugaran Jasmani, (Gresik: Abil Pustaka, 2011), hlm. 19.

${ }^{13}$ Nurhasan, Tips Praktis Menjaga Kebugaran Jasmani, (Gresik: Abil Pustaka, 2011), hlm. 19- 
ukuran keadaan gizi pada seseorang dengan memperhitungkan kecukupan zat-zat gizi yang diperoleh dari makanan yang dikonsumsi setiap harinya. Kebutuhan gizi harus mengandung protein, lemak, karbohidrat, garam mineral, vitamin dan air yang seimbang.

3. Manfaat kebugaran jasmani

Derajat kebugaran jasmani seseorang sangat menentukan kemampuan fisiknya dalam melaksanakan tugas-tugasnya sehari-hari. Semakin tinggi kebugaran jasmani seseorang maka semakin tinggi pula kemampuan kerja fisiknya. Dengan kata lain, hasil kerjanya kian produktif apabila kebugaran jasmaninya semakin meningkat.

Fungsi kebugaran jasmani selain untuk menunjukkan kondisi fisik dapat dibagi menjadi tiga golongan yaitu; 1) Golongan yang dihubungkan dengan pekerjaan seperti: a) Bagi olahragawan adalah meningkatkan prestasi, b) Bagi karyawan adalah untuk meningkatkan efisiensi dan produktivitas kerja, c) Bagi pelajar dan mahasiswa berguna untuk meningkatkan prestasi belajar. 2) Golongan yang dihubungkan dengan keadaan seperti: a) Bagi penderita cacat digunakan untuk rehabilitasi, b) Bagi ibu hamil sangat penting untuk perkembangan bayi yang dikandung dan mempersiapkan kondisi fisik pada saat melahirkan, 3) Golongan yang dihubungkan dengan usia yaitu : a) Bagi anakanak adalah untuk menjamin pertumbuhan dan perkembangan secara optimal, b) Bagi orang tua adalah untuk mempertahankan kondisi fisik agar tetap segar dan tidak mudah terserang penyakit.

\section{B. METODE PENELITIAN}

Penelitian ini termasuk jenis penelitian kuantitatif dengan menggunakan pendekatan metode eksperimental. Penelitian eksperimen adalah suatu penelitian yang dilakukan secara ketat untuk mengetahui hubungan sebab akibat diantara variable-variabel. ${ }^{14}$ Sedangkan bentuk rancangan penelitian yang digunakan adalah “one-group pretest-postest design".

Keterangan :

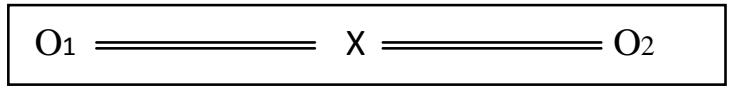

O1 : Pretest (Tes awal)

$\mathrm{X}$ : Treatment (Perlakuan)

O2 : Posttest (Tes akhir)

\section{Variabel Penelitian}

1. Variabel bebas $(\mathrm{X})$ adalah latihan senam kebugaran jasmani

2. Variabel terikat (Y) adalah kebugaran jasmani

Instrumen Penelitian

Instrumen yang digunakan untuk mengetahui tingkat kebugaran jasmani adalah tes TKJI yang terdiri dari 5 tes, antara lain: 1) Lari cepat 60 meter, 2) Gantung angkat tubuh dan gantung tekuk siku, 3) Baring duduk, 4) Loncat tegak, dan 5) Lari 600 meter. Berdasarkan pada penelitian ini yaitu mengkaji tentang pengaruh latihan senam kebugaran jasmani tehadap peningkatan kebugaran jasmani maka test ini digunakan untuk menggunakan independen group test dan mengetahui apakah ada perbedaan atau kesamaan antara kedua data.

\footnotetext{
${ }^{14}$ Maksum, Metodologi Penelitian Dalam Olahraga, (Surabaya: Unesa, 2008), hlm. 11.

Vol. 1 No. 1 / April 2018

$\mathrm{Al}$ - Mudarris homepage: http://e-journal.staima-alhikam.ac.id/index.php/al-mudarris/
} 


\section{HASIL PENELITIAN}

Bedasarkan hasil analisis data yang sudah dilakukan, maka diperoleh deskripsi data dan akan dibahas dalam hasil penelitian, deskripsi data ini terdiri dari hasil uji coba instrumen, deskripsi data pre-test, dan deskripsi post-test yang akan dianalisis melalui uji homogenitas, uji normalitas dan uji hipotesis.

1. Hasil pre-test

a. Uji normalitas pre-test

Uji normalitas dilaksanakan untuk melihat apakah sampel yang diambil dari populasi memiliki distribusi normal atau tidak dengan hipotesis pembuktian

Ho: Sampel berasal dari populasi yang distribusinya normal

Ha: Sampel tidak berasal dari populasi yang berdistribusi normal.

b. Uji homogenitas pre-test

Pengujian homogenitas menggunakan uji kesamaan dua varian. Hasil perhitungan pada normalitas diperoleh nilai varian untuk tes kebugaran jasmani pada kelas exsperimen sebesar 17,68 dan pada kelas control sebesar 19,51 hipotesis yang akan dibuktikan

Ho: Tidak terdapat perbedaan varian kelas exsperimen dengan varian kelas kontrol (Homogen)

Ha: Terdapat perbedaan varian kelas exsperimen dengan varian kelas kontrol (tidak homogen)

2. Hasil post-test

a. Uji normalitas post-test

Untuk mengetahui pengaruh latihan senam kebugaran jasmani terhadap kebugaran jasmani peserta didik, maka peserta didik diberi tes berupa tes kebugaran jasmani yang dilakukan diakhir treatment

Ho: sampel berasal dari populasi yang bedistribusi normal

Ha: sampel tidak berasal dari populasi yang berdistribusi normal

b. Uji homogenitas post-test

Sebelum melakukan pengujian hipotesis data yang diperoleh harus homogen. hasil tes nilan varian pada kelas exsperimen sebesar 2,65 dan pada kelas kontrol sebesar 1,71 hipotesis yang akan dibuktikan:

Ho: tidak terdapat perbedaan varian kelas exsperimen dengan varian kelas control (homogen)

Ha: terdapat perbedaan varian kelas exsperimen dengan varian kelas kontrol (tidak homogen)

c. Uji hipotesis

Rumus yang pakai untuk menguji hipotesis perbedaan dua rata-rata yang digunakan untuk melihat ada atau tidak adanya perbedaan atau kesamaan antara dua data maka teknik analisis statistik untuk menguji beda rata-rata adalah test $(\mathrm{T})$

Ho: tidak ada pengaruh antara latihan senam kebugaran jasmani 3 kali seminggu terhadap tingkat kebugaran jasmani pada siswa kelas V MIN Donomulyo Kabupaten Malang

Ha: ada pengaruh yang positif latihan senam kebugaran jasmani 3 kali seminggu terhadap tingkat kebugaran jasmani pada siswa kelas V MIN Donomulyo Kabupaten Malang

Vol. 1 No. 1 / April 2018

$\mathrm{Al}$ - Mudarris homepage: http://e-journal.staima-alhikam.ac.id/index.php/al-mudarris/ 
Bedasarkan hasil penelitian dan analisis data yang telah dilakukan terhadap latihan senam kebugaran jasmani 3 kali seminggu terdapat peningkatan kebugaran jasmani pada peserta didik sekolah dasar.

\section{KESIMPULAN}

Hasil penelitian tentang pengaruh latihan SKJ terhadap tingkat kebugaran jasmani siswa kelas V MIN Donomulyo Kabupaten Malang. Maka dapat disimpulkan bahwa terdapat pengaruh signifikan pemberian latihan senam kebugaran jasmani terhadap tingkat kebugaran jasmani siswa kelas $\mathrm{V}$ MIN Donomulyo Kabupaten Malang

\section{DAFTAR PUSTAKA}

Bompa, T.O. Periodization theory and methodology of training. United states: Human kinetics. 2009

Maksum, Ali. Metodologi Penelitian Dalam Olahraga. Surabaya: Unesa University Press. 2008.

Muhajir.. Pendidikan Jasmani, Olahraga, dan Kesehatan. Jakarta. 2017

Nurhasan. Tips Praktis Menjaga Kebugaran Jasmani. Gresik: Abil Pustaka. 2011

Suharno. Ilmu Coaching umum. Yogyakarta: FKIK IKIP Yogyakarta. 1986 